\title{
DETERMINANTS OF FINANCIAL DEVELOPMENT: IMPACT OF HUMAN CAPITAL IN EMERGING MARKETS COUNTRIES
}

\author{
Syafira Illaina Maghfiroh ${ }^{1}$, Rudi Purwono ${ }^{2}$ \\ ${ }^{1}$ syafira.illaina.maghfiroh-2020@feb.unair.ac.id \\ Universitas Airlangga \\ Jl. Airlangga No.4 - 6, Airlangga, Kec. Gubeng, Kota Surabaya, Jawa Timur 60115
}

received: 28/5/21; revised: 31/7/21; approved: 20/12/21

\begin{abstract}
This study aims to examine determinants of financial development and see role of quality of human capital in financial development in 19 Emerging Market countries during 2008-2017. Financial development in this study is proxied using the financial development index to accommodate multidimensional of financial development. Estimation is using the dynamic panel method Generalize Method of Moment (GMM). The results show that the quality of human capital has contributed to increasing financial development in emerging market countries in 2008-2017. Meanwhile, trade openness and government expenditure do not have a statistically significant effect and domestic savings have a significant positive effect on financial development.
\end{abstract}

Keywords: financial development; human capital; dynamic panel; Emerging Markets

\section{INTRODUCTION}

Emerging Markets (EMs) economies are growing rapidly or are transitioning to higher levels of GDP (Mody, 2004). Rapid economic growth in Emerging Markets (EMs) has become engine of the global economy, with a proportion of 59\% of total global GDP (Muller, 2018). One of the main drivers that contributing to high economic growth is the role of domestic financial markets and institutions (Dorrucci, et al., 2009). High economic growth in Emerging Market countries indicates good financial system, because good economic performance is associated with good financial development (Fung, 2009; Abubakar, et al., 2015).

In endogenous growth theory, one of important factors that drives long-term economic growth is financial development, where financing can facilitate economic growth by opening opportunities for efficient resource allocation, capital accumulation and technological innovation (Levine, 2005). Financial development is an effort to promote intermediation function of financial institutions which is useful for higher economic performance and then improve people's welfare. Financial development reduces asymmetry information and financial constraints such as expensive transaction costs and also can increase the ability of the financial system to absorb shocks (Bernanke, et al., 1999) and reduce macroeconomic volatility (Dabla-Norris \& Srivisal, 2013).

Financial development is a multidimensional process, which is a combination of depth, access and efficiency of the financial sector (Svirydzenka, 2016). The process involves a combination of various activities and institutions that cannot be captured in just one measurement. The financial development index are able to describe the multidimensional process of financial development, because it includes depth, access and efficiency of the financial sector (Svirydzenka, 2016) compared to only depth indicators such as domestic credit to the private sector to GDP, percentage of M2 to GDP (Rousseau \& Sylla, 2001; King \& Levine, 1993) or stock market capitalization to GDP (Naceur, et al., 2014).

Because of positive impact that financial development give to the economy, It is important to do research on the factors that affect financial development, especially in Emerging Market countries. Emerging Markets countries were selected as research objects because according to the IMF (2017) economic growth rate in Emerging Markets countries is relatively higher than Advanced Markets countries however, its financial development is still lower than Advanced Markets. Thus, the determinants of financial development in Emerging Markets countries need to be further explored and researched.

Financial development is influenced by so many factors, from macroeconomic factors to institutional factors and also human capital. Human capital cannot be ruled out in the financial development process. Chou \& Chinn 
(2001) found that human capital is a key factor in creating greater financial innovation in financial products and financial intermediaries which in turn improves financial development, as well as Outreville (1999) who concludes that human resources are a vital factor in explaining financial development. The higher education is related to better quality of human resources, and helps in improving financial development as well (Hatemi-J \& Shamsuddin, 2016). In particular, higher education which represents human capital positively affects financial development (Khalfaoui, 2015; Hakeem \& Oluitan, 2012) because people with higher educational backgrounds have higher levels of financial literacy which is related to having more knowledge about financial products (Eryigit, et al., 2015).

In Emerging market countries even development of the financial sector is presently witnessing, low human capital can hamper innovation and ingenuity thus inhibiting the potential growth effects of the financial sector. Human capital is the main factor that drives financial development and shows a positive influence on financial development (Khan, et al, 2020; Zaidi, et al, 2019; Ibrahim \& Sare, 2018). Human resources play central role in accelerating development of the financial sector by strengthening demand and supply of money and financial services and then improving the quality of life (Zaidi, et al, 2019). Human resources contribute to financial development because they strengthen financial system through technology then increases economic growth (Zafar, et al, 2019). Highly educated people have better access to information so they tend to behave less risky and create higher savings (Outreville 1999; Kelly, 1980).

Meanwhile, financial development is also influenced by trade openness and inflation. Law \& Demetriades (2006) and Law \& Habibullah (2009) conclude that trade openness is one of the most effective determinants of financial development. When a country is open to trade and capital flows, it is more likely to develop its financial system as it promotes competitive markets (Badeeb, et al., 2017; Baltagi, et al., 2009; Huang \& Temple, 2005; Kim, et al., 2010; Svaleryd \& Vlachos, 2002). Beck, et al., (2002) argues that macroeconomic factors such as inflation affect financial development, this is also supported by Krause \& Rioja (2006). Financial development, one of which depends on policies regarding price increases, high inflation has an adverse effect on financial development and financial development increases when the real value of money rises when inflation is low.

Furthermore, Demetriades \& Rousseau (2010) and Ibrahim \& Sare (2018) considered government expenditure as determinants of financial development. Naceur, et al., (2014) included government expenditure as an indicator of macroeconomic stability and found a negative effect on financial sector development. Government expenditure increases the need for domestic financing, and hinders the effectiveness of intermediaries in mobilizing savings to support private sector activities. In addition, the role of savings also supports the development of the financial sector as in research Ibrahim \& Sare (2018), Huang (2010), and Naceur, et al, (2014). country with high savings indicates a deeper financial system and has a positive impact on the demand for financial services (Edwards, 1996).

The purpose of this study is to examine the determinants of financial development and determine whether human capital has an influence on financial development in 19 Emerging Markets countries. Then whether there is an influence from other variables in the study, namely trade openness, government expenditure, inflation and domestic savings on financial development.

\section{METHODS}

This study uses secondary data, data that is obtained indirectly through various sources or sites related to the research. This study is using panel dataset of 19 countries that are included in Emerging Markets cointries category from total of 26 countries according to the Morgan Stanley Capital Information (MSCI) classification that selected according to data availability. The time series data used is annual data spanning from 2008 to 2017 obtained from World Development Indicators (WDI) by World Bank and also from International Monetary Fund (IMF).

This study uses a dynamic panel regression method with System Generalized Method of Moment (GMM), to estimate relationship between dependent variable namely financial development and all independent variables in the model. The dynamic panel method includes lag of the dependent variable as a regressor in the regression. The GMM method is used because it can reduce bias, which might occur when using the OLS, PLS, FEM, REM methods (Aggarwal, et al., 2011). GMM is used to eliminate endogeneity that may be due to the correlation of country-specific and time-invariant factors.

To estimate determinants of financial development, especially the role of human capital for financial development, following previous studies, model in this study includes other economic variables that are important for financial development such as trade openness, government expenditure, inflation, and domestic savings (Ibrahim \& Sare, 2018; Abubakar, et al., 2015).

The model that is formed mathematically is written as follows: 


$$
\text { FINDEV }_{\text {it }}=\alpha_{0} \operatorname{FINDEV}_{\mathrm{it}-1}+\alpha_{1} \operatorname{HCAP}_{\mathrm{it}}+\alpha_{2} \mathrm{OPEN}_{\mathrm{it}}+\alpha_{3} \operatorname{GOVEXP}_{\mathrm{it}}+\alpha_{4} \mathrm{INF}_{\mathrm{it}}+\alpha_{5} \mathrm{DS}_{\mathrm{it}}+\varepsilon_{\mathrm{it}}
$$

where:

FINDEV $_{\text {it }} \quad=$ financial development

FINDEV $_{\mathrm{it}-1} \quad=$ lagged financial development

$\mathrm{HCAP}_{\text {it }} \quad=$ human capital

OPEN $_{\text {it }} \quad=$ trade openness

GOVEXP $_{\text {it }}=$ government expenditure

$\mathrm{INF}_{\text {it }} \quad=$ inflation

$\mathrm{DS}_{\mathrm{it}} \quad=$ domestic savings

$\varepsilon_{\text {it }}$

$=$ error term

Financial development expressed by financial development index issued by IMF which includes depth, access and efficiency aspects of the financial sector, which thus includes three dimensions of four dimensions of financial development according to World Bank. School enrollment tertiaty gross that is ratio of total enrollment in tertiary education, regardless of age that officially corresponds to the level of education shown to proxy human capital. Trade openness is measured as total of exports and imports of goods and services as a share of GDP. Government expenditure described as a percentage of GDP. Inflation is potray as annual percentage change of consumer price index. Domestic saving sare using calculation of gross domestic saving.

\section{RESULTS}

Tabel 1 provides descriptive statistic of variables used in this research with 190 observations in total. The panel dataset contains 19 Emerging Markets countries (Brazil, Chile, China, Colombia, Czech Republic, Egypt, Greece, Hungary, India, Indonesia, Korea, Malaysia, Mexico, Pakistan, Philippines, Poland, Qatar, Saudi Arabia, Thailand) over the period 2008-2017.

Table 1. Descriptive statistics

\begin{tabular}{lccccc}
\hline \multicolumn{1}{c}{ Variabel } & Observasi & Mean & Standar Deviasi & Min & Max \\
\hline Financial Development & 190 & 0.4842685 & 0.1466207 & 0.1709273 & 0.8684537 \\
Human Capital & 190 & 48.13567 & 27.81403 & 5.55547 & 136.6026 \\
Trade Openness & 190 & 77.71399 & 41.23815 & 22.10598 & 176.6683 \\
Government Expenditure & 190 & 15.00788 & 4.253716 & 8.423781 & 30.00348 \\
Inflation & 190 & 4.253515 & 4.122252 & -4.863278 & 29.50193 \\
Domestic Savings & 190 & 28.33227 & 14.62879 & 1.783862 & 75.54961 \\
\hline
\end{tabular}

Source: Output STATA 14, 2020

Estimation results presents in Table 1 about determinants of financial development using System-GMM shows that human capital, inflation, and domestic savings has significant effect on financial development. On the other hand, significance is not seen in trade openness and government expenditure variables.

Human capital, which is proxied by tertiary gross school enrollment and domestic savings, which is measured using annual data on the percentage of gross domestic savings to Gross Domestic Product has a significant positive effect on financial development. Meanwhile, inflation has a significant effect on financial development with a negative sign. The positive sign indicates that if this variable has increased, it will also increase financial development. While the negative sign means that if the variable has increased, it will decrease financial development.

\section{DISCUSSIONS}

Based on the estimation results, human capital variable has a significant positive effect on financial development. This result is in line with endogenous growth theory that increasing in physical and human capital can lead to much higher growth and emphasizes that there is a complementary nature between financial market development and capital accumulation. These results are consistent with previous studies that human capital positively affects financial development (Khan, et al, 2020; Ibrahim \& Sare, 2018; Elsherif, 2015; Seetanah, et al, 2010; Evans, et al., 2002). 
Human capital is one of the important factors that contribute to financial development (Zafar, et al, 2019; Cleeve, et al., 2015; Outreville, 1999; Lucas, 1990; Dunning, 1988). Human capital accumulation significantly increases financial development (Hatemi \& Shamsuddin, 2016; Eryiğit, et al., 2015; Sibel, et al., 2015; Arora \& Ratnasiri, 2011; Outreville, 1999). In addition, when human resources are deepened through attainment of quality of education, individuals become more aware of risk analysis and can increase their risk-taking capacity thereby, in the short term also increasing demand for investment and credit. individuals can diversify their risk and channel their credit into more productive investments with an informed risk analysis.

Sapkota and Bastola (2017) states, human capital brings knowledge about global and domestic financial system, then generates demand for high-quality products and services from financial institutions. Human resources strengthen demand and supply of money and financial services in society, which makes a positive contribution to financial development. Education open the opportunities of people to move from informal sector to formal sector financial services (Kargbo, et al., 2016).

Table 2. System-GMM Estimations

\begin{tabular}{lccc}
\hline \multicolumn{1}{c}{ Variables } & Coefficient & & Standard Error \\
\hline L.Financial Development & $0.8255^{* * *}$ & & $(0.041)$ \\
Human Capital & $0.0005^{* * *}$ & & $(0.000)$ \\
Trade Openness & 0.0001 & & $(0.000)$ \\
Government Expenditure & -0.0000 & & $(0.000)$ \\
Inflation & $-0.0015^{* * *}$ & & $(0.000)$ \\
Domestic Savings & $0.0007^{* * *}$ & & \\
Prob>F & & 0.000 & \\
Ar(1) & & 0.015 & \\
Ar(2) & & 0.850 & \\
Sargan Test & & 0.953 & \\
Hansen Test & & 0.792 & \\
GMM Hansen Test & & 0.424 & \\
GMM Diff Hansen & & 0.908 & \\
IV Hansen Test & & 0.836 & \\
IV Diff Hansen & & 0.457 & \\
Notes: $(* * *)$ Denote significance at $1 \%,(* *)$ Denote significance at $5 \%,(*)$ Denote significance \\
at 10\%, (without *) not significant.
\end{tabular}

Table 2 shows that trade openness is not significant for financial development, this means that integration with international markets does not increase financial development. These findings are similar to previous study that also found that trade openness does not affect financial development (Ibrahim \& Sare, 2018; Law \& Habibullah, 2009; Altaee, et al, 2014; David, et al., 2014; Muhammad, et al., 2016) . Greater openness to world goods markets can amplify domestic economic fluctuations (Arora \& Vamvakidis, 2004; Blankenau, et al., 2001; Rodrik, 1998) and / or lead to increased vulnerability to external shocks (Loayza \& Raddatz, 2007; Tornell, et al., 2004), which can exacerbate capital market imperfections and consequently hinder financial development.

Similar with trade openness, government expenditure has no significant effect on financial development, this is similar with Demetriades \& Rousseau (2010) finding. In case of some countries, government expenditure is dependent on foreign aid and international loans and thus has no impact on domestic financial development. Increasing government expenditure may not have a beneficial effect in developing countries, the evidence is there is many countries in the Emerging Markets group are still classified as developing countries where the level of public debt is still high. Government consumption suppresses private investment, reduces economic stimulus in the short term and reduces capital accumulation in the long run. In addition, volatility of government expenditure plays an important role in increasing economic fluctuations.

The estimation results of System-GMM on inflation show a significant negative effect on financial development. Although the empirical findings on the subject are diverse, evidence in emerging market countries point to a negative effect of inflation. Investigation about Brazil on the role of inflation for financial development, concludes that inflation is detrimental to financial development (Bittencourt, 2008). In addition, Choi, et al. (1996) investigated data from 4 countries include Chile and Korea report that inflation has negative impact on financial development. These results are similar to other empirical findings which state the same thing (Ibrahim 
\& Sare 2018; Zainudin \& Nordin 2017; Badeeb, et al, 2017; Ayadi, et al, 2014; Boyd, et al., 2001; Chinn \& Ito, 2002, 2005; Elsherif, 2015; Huybens \& Smith, 1998; Padachi, et al., 2008; Seetanah, et al, 2010). Economies with macroeconomic conditions that tend to be unstable are more likely to have underdeveloped financial systems than economies with more stable macroeconomic conditions, especially those with low inflation. This is consistent with theory that higher inflation is associated with macroeconomic instability and therefore impairs the ability of financial institutions to effectively allocate and distribute financial resources (Boyd, et al., 2001).

Countries with high inflation periods will reduce intermadiation capacity of the financial sector and destabilize efficient financial intermediation and hinder the purchase of financial assets and credit extension (Rousseau \& Wachtel, 2001; Khalfaoui, 2015). Huybens \& Smith (1998) argues that the information asymmetry generated by high inflation rates will negatively affect the credit market as well as performance of financial sector.

The domestic saving variable has a significant positive effect on financial development which supports McKinnon (1973) hypothesis or called financial development model that reducing financial restrictions (removing interest rate ceilings, reducing reserve requirements and expanding credit facilities) will stimulate higher savings. These results are also consistent with the findings of Liu \& Woo (1994), Granville \& Mallick (2004), Odhiambo (2008), and Ang (2010) regarding a positive relationship between savings and financial sector development. Khan \& Hye (2010) argue that a developing financial system is characterized by increased opportunities for saving, which also includes higher savings rates, and number of savings options that offer better returns.

\section{CONCLUSIONS}

The estimation results of determinants of financial development in 19 Emerging Markets (EMs) countries from 2008 to 2017 show that human capital and domestic savings have significant positive effect on financial development, while inflation has negative and significant effect on financial development. Furthermore, trade openness and government expenditure do not have a significant effect on financial development.

These results have implications for the need to increase technological innovation and human resource development to encourage the development of financial sector. The positive influence of human capital on financial development indicates the importance of improving the quality of human capital, which can be done by increasing access to and quality of education in order to encourage an increase in the function of financial intermediation which is useful for improving the economy and the welfare of society.

\section{REFERENCES}

Abubakar, A., Kassim, S. H., \& Yusoff, M. B. 2015. Financial Development, Human Capital Accumulation and Economic Growth: Empirical Evidence from the Economic Community of West African States (ECOWAS). Social and Behavioral Sciences 172, 96- 103.

Aggarwal, R., Demirguc-Kunt, A., \& Peria, M. 2011. Do Remittances Promote Financial Development? Journal Development Econnomics, 96 (2), 255-264.

Altaee, H. H., Saied, S. M., Esmaeel, E. S., \& Adam, M. H. 2014. Financial Development, Trade Openness and Economic Growth: Evidence from Sultanate of Oman (1972-2012). Journal of Economics and Sustainable Development, 5 (23).

Ang, J. 2010. Savings Mobilisation, Financial Development and Liberalization: The Case of Malaysia. MPRA Paper (21718).

Arora, R. U., \& Ratnasiri, S. 2011. Financial Development, Financial Inclusion and Human Capital: How Close is the Link? A Study of India. Paper Presented in the Indian Economy. Australian National University .

Arora, V., \& Vamvakidis, A. 2004. How Much do Trading Partners Matter for Economic Growth? IMF Working Paper (04/26).

Ayadi, R., Arbak, E., Naceur, S. B., \& De Groen, W. P. 2014. Determinants of Financial Development Across the Mediterranean. Economic and Social Development of the Southern and Eastern Mediterranean Countries , 159-181.

Badeeb, R. A., Lean, H. H., \& Clark, J. 2017. The Evolution of the Natural Resource Curse Thesis: a Critical Literature Survey. Resource Policy, 51, 123-134.

Baltagi, B. H., Demetriades, P. O., \& Law, S. H. 2009. Financial Development and Openness: Evidence from Panel Data. Journal of Development Economics , 89, 285-296.

Beck, T. 2002. Financial Development and International Trade: is There a Link? Journal International Economy. 57, 107-131.

Bernanke, B., Gertler, M., \& Gilchrist, S. 1999. The Financial Accelerator in a Quantitative Business Cycle Framework. NBER Working Paper, 6455. 
Bittencourt, M. 2011. Inflation and Financial Development: Evidence from Brazil, Economic Modelling, 28, 91-99.

Blankenau, W., Kose, M., \& Yi, K. 2001. Can World Real Interest Rates Explain Business Cycles in a Small Open Economy? Journal of Economic Dynamics and Control, 25, 867-889.

Boyd, J. H., Levine, R., \& Smith, B. D. 2001. The Impact of Inflation on Financial Sector Performance. Journal of Monetary Economics, 47, 221-248.

Chinn, M. D., \& Ito, H. 2002. Capital Account Liberalization, Institutions and Financial Development: Cross Country Evidences. NBER Working Paper Series (8967).

Chinn, M., \& Ito, H. 2005. What Matters for Financial Development? Capital Controls, Institutions, and Interactions. La Follette School Working Paper (2005-007).

Choi, S., Smith, B. D., \& Boyd, J. H., 1996. Inflation, Financial Markets, and Capital Formation. Federal Reserve Bank of St. Louis Review.

Chou, Y., \& Chinn, M. 2001. Human Capital, Financial Innovations and Growth: A Theoretical Approach. Research Paper Series, No 826, Department of Economics, University of Melbourne .

Cleeve, E. A., Debrah, Y., \& Yiheyis, z. 2015. Human Capital and FDI Inflow: an Assessment of the African Case. World Development, 74, 1-14.

Dabla-Norris, E., \& Srivisal, N. 2013. Revisiting the Link between Finance and Macroeconomics Volatility. IMF Working Paper, 13/29.

David, A. C., Mlachila, M., \& Moheeput, A. 2014. Does Openness Matter for Financial Development in Africa? International Monetary Fund Working Paper, Number WP/14/94., hal. 1-37.

Demetriades, P. O., \& Rousseau, P. L. 2010. Government, Trade Openness and Financial Development. NBER working paper .

Dorrucci, E., Meyer-Cirkel, A., \& Santabárbara, D. 2009. Domestic Financial Development In Emerging Economies Evidence And Implications. European Central Bank, Occasional Paper series 102 .

Dunning, J. 1988. The Eclectic Paradigm of International Production: a Restatement and Some Possible Extensions. Journal International Business Study, 19 (1), 1-31.

Edwards, S. 1996. Why Are Latin America's Saving Rate So Low: An International Comparative Analysis. Journal of Development Economics, 51.

Elsherif, M. A. 2015. The Determinants of Financial Development: Empirical Evidence from Egypt. The Macrotheme Review, 4 (3).

Eryiğit, S. B., Eryigit, K. Y., \& Dulgeroglu, E. 2015. Local Financial Development and Capital Accumulations: Evidence from Turkey. Panoeconomicus, 62 (3), 339-360.

Evans, A. D., Green, C. J., \& Murinde, V. 2002. Human Capital and Financial Development in Economic Growth: New Evidence Using the Translog Production Function. International Journal of Finance \& Economics, 7 (2), 123-140.

Fung, M. K. 2009. Financial Development and Economic Growth: Convergence or Divergence? Journal of International Money and Finance, 28 (1), 56-67.

Granville, B., \& Mallick, S. 2004. Pension Reforms and Saving Gains in the UK. The Journal of Policy Reform, 7 (2), 123-136.

Hakeem, M., \& Oluitan, O. 2012. Financial Development and Human Capital in South Africa: A Time-Series Approach. Research in Applied Economics, 4 (3).

Hatemi-J, A., \& Shamsuddin, M. 2016. The Causal Interaction Between Financial Development and Human Development in Bangladesh. Appl. Econ. Lett, 23, 995-998.

Huang, Y. 2010. Determinants of Financial Development. London: Palgrave Macmillan.

Huang, Y., \& Temple, J. 2005. Does External Trade Promote Financial Development? Department of Economics, University of Bristol, UK, 05/575.

Huybens, E., \& Smith, B. 1998. Financial Market Frictions, Monetary Policy, and Capital Accumulation in a Small Open Economy. Journal of Economic Theory, 81 (2), 353-400.

Ibrahim, M., \& Sare, Y. A. 2018. Determinants of Financial Development in Africa: How Robust is the Interactive Effect of Trade Openness and Human Capital? Economic Analysis and Policy, 60, 18-26.

IMF. 2017. World Economic Outlook. Washington, D.C: International Monetary Fund.

Kargbo, A. A., Ding, Y., \& Kargbo, M. 2016. Financial Development, Human Capital, and Economic Growth: New evidence from Sierra Leone. Journal of Finance and Bank Management, 4 (1), 49-67.

Kelly, A. 1980. Interactions of Economic and Demographic Household Behavior in Easterlin Population. Chicago, IL: Chicago University Press.

Khalfaoui, H. 2015. The Determinants of Financial Development: Empirical Evidence from Developed and Developing Countries. Applied Economics and Finance, 2 (4). 
Khan, R. E., \& Hye, Q. M. 2010. Financial Sector Reforms and Household Savings in Pakistan: An ARDL Approach. African Journal of Business Management, 4 (16), 3447-3456.

Khan, Z., Hussain, M., Shahbaz, M., Yang, S., \& Jiao, Z. 2020. Natural Resource Abundance, Technological Innovation, and Human Capital Nexus with Financial Development: A case Study of China. Resources Policy, 65 (101585).

Kim, D. H., Lin, S. C., \& Suen, Y. B. 2010. Dynamic Effects of Trade Openness on Financial Development. Economic Modelling, 27 (1), 254-261.

King, R., \& Levine, R. 1993. Finance and Growth: Schumpeter Might be Right. The Quarterly Journal of Economics , 108 (3), 717-737.

Krause, S., \& Rioja, F. 2006. Financial Development and Monetary Policy Efficiency. Working Paper, Georgia University .

Law, S. H., \& Demetriades, P. 2006. Openness, Institutions and Financial Development. WEF Working Paper (12).

Law, S. H., \& Habibullah, M. S. 2009. The Determinants of Financial Development: Institutions, Openness and Financial Liberalisation. South Africa Journal Economy, 7 (11), 45-58.

Levine, R. 2005. Finance and Growth: Theory and Evidence. NBER Working Paper, 10766.

Liu, L.-Y., \& Woo, W. T. 1994. Saving Behavior under Imperfect Financial Markets and the Current Account Consequences. Economic Journal, 104 (424), 512-527.

Loayza, N. V., \& Raddatz, C. 2007. The Structural Determinants of External Vulnerability. The World Bank Economic Review, 21 (3), 359-387.

Lucas Jr., R. 1990. Why Does not Capital Flow from Rich to Poor Countries. American Economic Review, 80, 92-96.

McKinnon, R. I. 1973. Money and Capital in Economic Development. Washington, DC: Brookings Institute.

Mody, A. 2004. What Is an Emerging Market? IMF Working Paper, WP/04/177.

Muhammad, S., Usman, M., \& Zafar, S. 2016. Trade Openness and Financial Development Nexus: An Empirical Study of Pakistan. Journal of Business and Economic Management, 4 (2), 50-54.

Muller, D. 2018. Emerging Markets - Powerhouse of Global Growth. Ashmore Investment Management Limited.

Naceur, S., Cherif, M., \& Kandil, M. 2014. What Drives the Development of the MENA Financial Sector? Borsa Istanbul Review , 14 (4), 212223.

Odhiambo, N. M. 2008. Interest Rate Reforms, Financial Depth and Savings in Tanzania: A Dynamic Linkage. Savings and Development, 32 (2), 141-158.

Outreville, J. F. 1999. Financial Development, Human Capital and Political Stability. Working Paper UNCTAD, 142.

Padachi, K., Seetanah, B., \& Rojid. 2008. The Determinants of FDI in Mauritius: A Dynamic Time Series Investigation. Working Paper.

Rodrik, D. 1998. Who Needs Capital-account Convertibility? Dalam S. FischFischer, R. Cooper, R. Dornbusch, P. Garber, C. Massad, J. Polak, et al., Should the IMF pursue capital-account convertibility? (hal. 55-65). Princeton, NJ: International Finance Section, Department of Economics, Princeton University.

Rousseau, P. L., \& Sylla, R. 2001. Financial Systems, Economic Growth, and Globalization. NBER Working Paper, 8323 .

Rousseau, P., \& Wachtel, P. 2001. Inflation, Financial Development and Growth. In: Negishi, T., Ramachandran, R., Mino, K. (Eds.), Economic Theory, Dynamics and Markets: Essays in Honor of Ryuzo Sato. Boston, MA: Kluwer Academic Press.

Sapkota, P., \& Bastola, U. 2017. Foreign Direct Investment, Income, and Environmental Pollution in Developing Countries: Panel Data Analysis of Latin America. Energy Econ., 64, 206-212.

Seetanah, B., Padachi, K., Hosany, J., \& Seetanah, B. 2010. Determinants of Financial Development: The Case of Mauritius. Finance and Corporate Governance Conference 2011 Paper.

Sibel, B. E., Kadir, Y. E., \& Ercan, D. 2015. Local Financial Development and Capital Accumulations: Evidence from Turkey. Panoeconomicus, 62, 339-360.

Svaleryd, H., \& Vlachos, J. 2002. Markets for Risk and Openness to Trade: How are They Related? Journal of International Economics, 57 (2), 369-395.

Svirydzenka, K. 2016. Introducing a New Broad-based Index of Financial Development. IMF Working Paper .

Tornell, A., Westermann, F., \& Martinez, L. 2004. The Positive Link Between Financial Liberalization, Growth and Crises. CESifo Working Paper Series, 1164.

Zafar, M., Saud, S., \& Hou, F. 2019. The Impact of Globalization and Financial Development on Environmental Quality: Evidence from selected countries in the Organization for Economic Co-operation and Development (OECD). Environ. Sci. Pollut. Res., 26, 13246-1326.

Zafar, M., Zaidi, S., Sinha, A., Gedikli, A., \& Hou, F. 2019. The Role of Stock Market and Banking Sector 
Development, and Renewable Energy Consumption in Carbon Emissions: insights from G-7 and N-11 countries. Resource Policy, 62, 427-436.

Zaidi, S. A., Wei, Z., Gedikli, A., Zafar, M. W., Hou, F., \& Iftikhar, Y. 2019. The Impact of Globalization, Natural Resources Abundance, and Human Capital on Financial Development: Evidence from thirty-one OECD countries. Resources Policy, 64, 101476.

Zainudin, N. B., \& Nordin, N. B. 2017. The Determinants of Financial Development in Four Selected ASEAN Countries: A Panel Data Analysis. International Journal of Business, Economics and Law, 12 (1). 